\title{
Determining the Spatial Trend of Water Quality Indices Across Kan and Karaj River Basins
}

\author{
Maryam Alizadeh ${ }^{1}$, Ruhollah Mirzaei ${ }^{2 *}$, Syed Hossein Kia $^{3}$ \\ 1. MSc in Environment, Faculty of Natural Resources and Earth Sciences,University of Kashan, Kashan, Iran \\ 2. Assistant Professor, Department of Environment, Faculty of Natural Resources and Earth Sciences, \\ University of Kashan, Iran \\ 3. Visiting Assistant Professor, Department of Environment, Faculty of Natural Resources, \\ University of Tarbiat Modarres, Tehran, Iran \\ *E-mail: rmirzaei@kashanu.ac.ir
}

Received: 16 Jan 2017 ; Accepted: 18 May 2017

\begin{abstract}
Background\& Objective: Due to the importance of water consumptions, this study aims to investigate the spatial trend of surface water quality along Kan and Karaj Rivers using three quality indices: NSFWQI, IRWQIsc and WQI.

Materials and Methods: The information of water quality parameters of 20 monitoring stations was collected to investigate water quality parameters along two mentioned rivers during 2012-2013, and water quality of two rivers were calculated using mentioned three quality indices. The parameters of TDS, FC, EC, nitrate and turbidity were used to measure the NSFWQI and IRWQIsc indices, and TDS, nitrate, and sulfate were used to calculate the WQI index. The measured parameters were compared with standards of drinking. The monitoring stations were grouped by cluster analysis and finally, the pattern of changes in water quality parameters and relevant quality indices were analyzed spatially using ArcGIS software.

Results: The water quality of Kan and Karaj Rivers based on NSFWQI index were in the range of bad and average quality, respectively. According to IRWQI $\mathrm{SC}_{\mathrm{SC}}$ index, water quality were in the range of very bad and relatively good, respectively and according to the WQI index water quality was in the range of good quality. The quality of upstream was acceptable for drinking and irrigation, on the basis of medium and good conditions of NSFWQI and IRWQISC, respectively. However, the downstream of both rivers are heavily polluted. The results of the clustering analysis stated that moving towards upstreamdownstream the quality of water decreases along both rivers.

Conclusion: The spatial trend analysis of water quality parameters along the rivers plays a crucial role for identifying the spatial variation of water quality. Also, availability of clean water depends on the geographical locations and topological situation across the basin.

Keywords: Water Quality, Cluster Analysis, Spatial Trend, GIS.
\end{abstract}





\title{
بررسى روند مكانى شاخصهاى كيفى آب در حوضة رودخانهاى كن و كرج
}

\author{
مريم علىزاده'، روح اله ميرزايى"،:، سيد حسين كيا؟ \\ ' كارشناس ارشد محيطزيست، كروه محيطزيست، دانشكده منابع طبيعى و علوم زمين، دانشكاه كاشان، كاشان، ايران

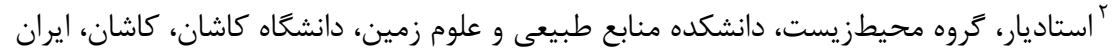

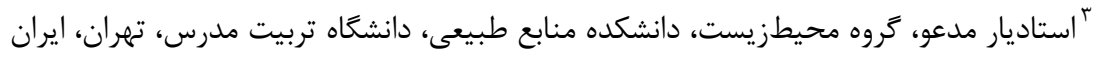

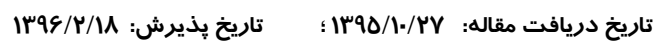

زمينه و هدف: با توجه به اهميت مصارف مختلف آب، هدف اين مطالعه بررسى روند مكانى كيفيت آب رودخانهایى كن و كرج با استفاده از سه

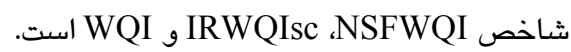

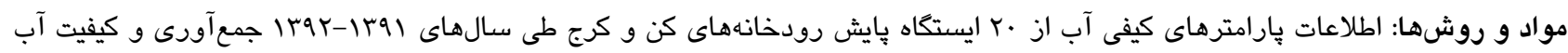

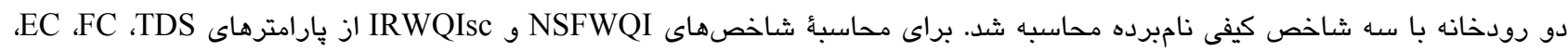

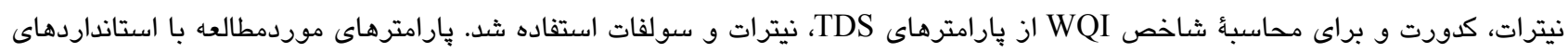

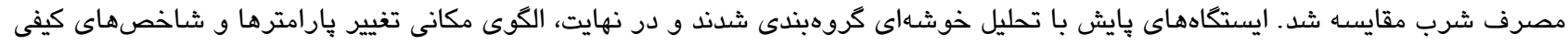

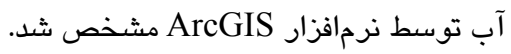

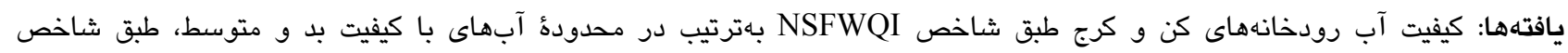
يهت IRWQISC

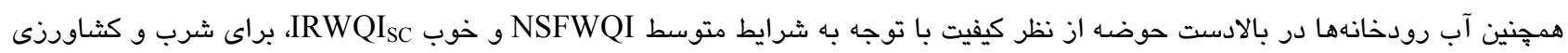

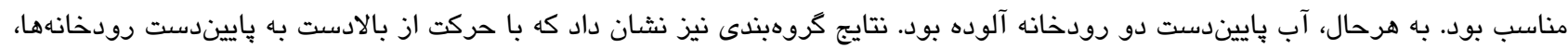
كيفيت آب كاهش مىيابد.

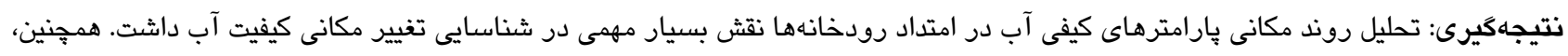

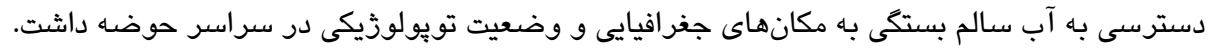


كويا از كيفيت آب به ويزهه براى مديران و تصميمسازان فراهم

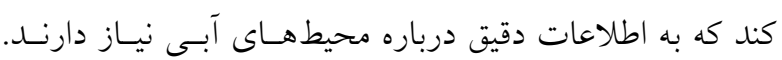

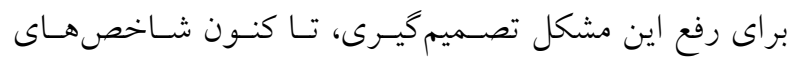

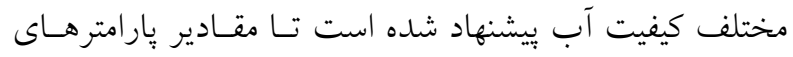

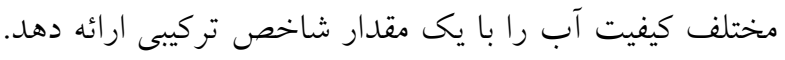

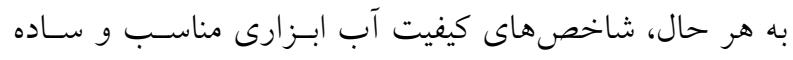

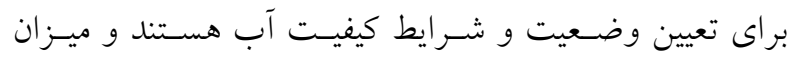

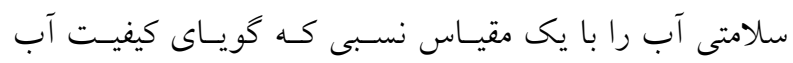

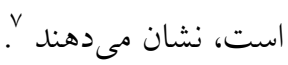

شـاخص كيفى ( National Sanitation Foundation Water NSFWQI (Quality Index

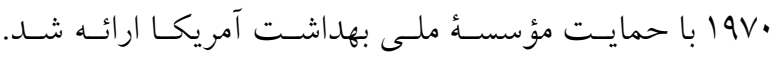
شاخصى بركاربرد جهت طبقهبندى كيفيت آبهاى NSFWQI

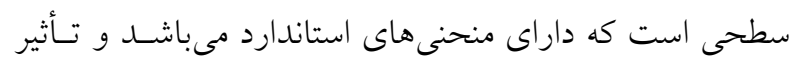

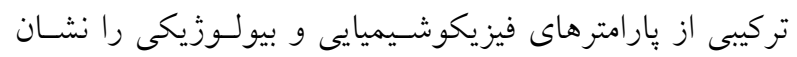

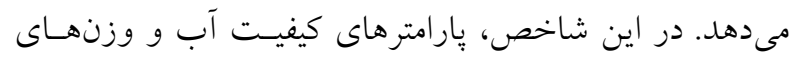

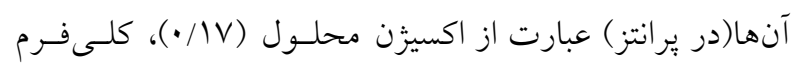

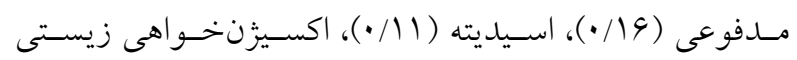

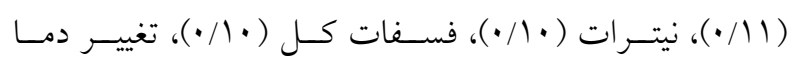

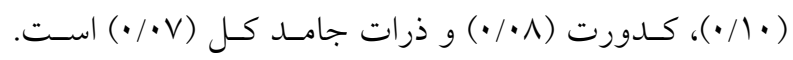

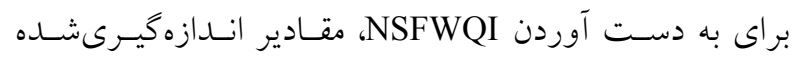

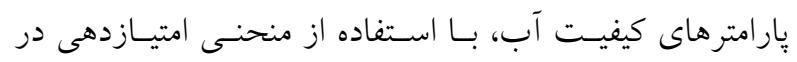

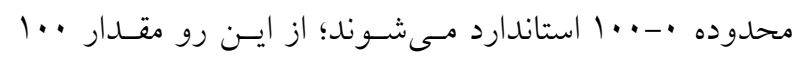

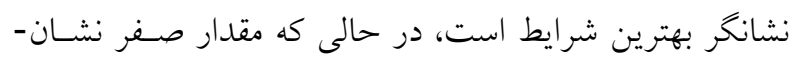

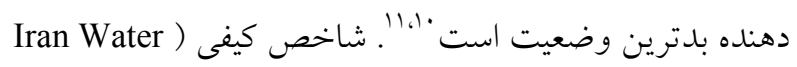
IRWQI (Quality Index for Surface Water متداول كيفيت آبهاى سطحى ايران است كه توسط هاشـمى

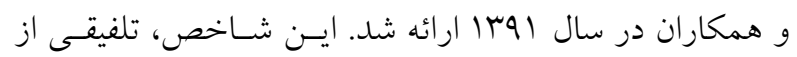
(British Columbia Water Quality Index) و NSFWQI مى باشد كه بر اسـاس نظـرات كارشناسـان حفاظـت

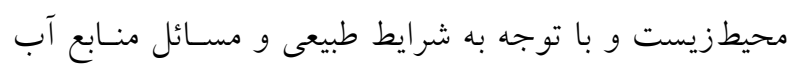

\section{مقدمه}

با توجه به توسـعه سـريع اقتصـادى و شهرنشسينى، كيفيـت و

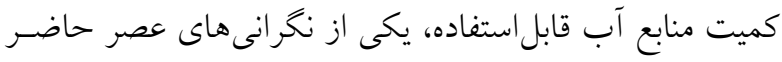

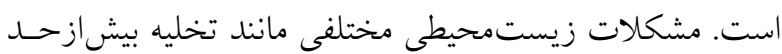
ضايعات صنعتى و كشاورزى بـه محسيط، كـاربرد نامناسـب و استفادة بىرويه از زمين، و بهـاشت ضعيف، تهديد جـــى در

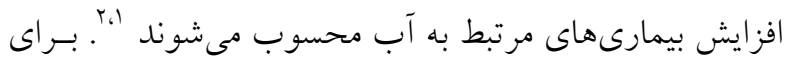

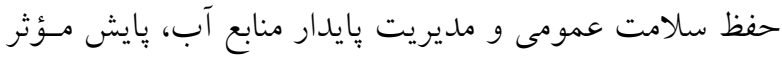

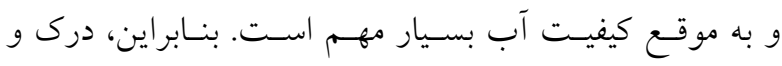

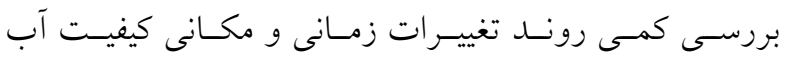

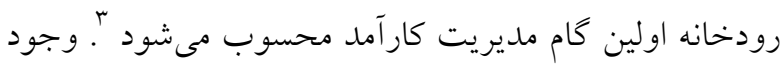

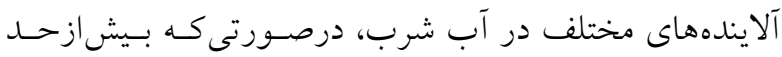
مجاز توصيه شــده در اسـتانداردها باشــن بـــاى بــدن در دراز مدت ايجاد بيمارى و آسيبهاى غيرقابل جبرانسى مسى نماينـد.

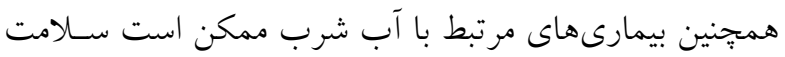

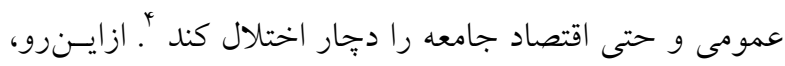

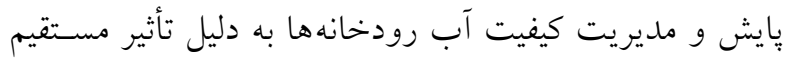
بر روى سلامت عمومى، بايدارى اكوسيستمهـاى آبسى، سـاير

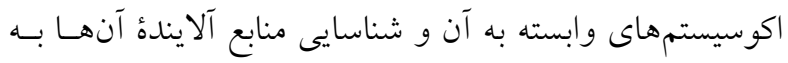
صورت معمول توسط سازمانهاى متولى صورت مى گيرد. بــه

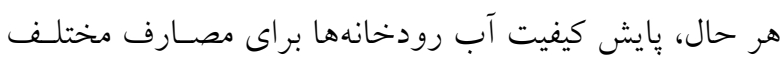

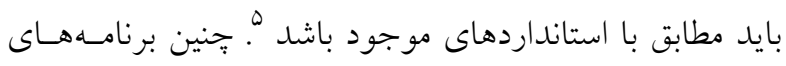

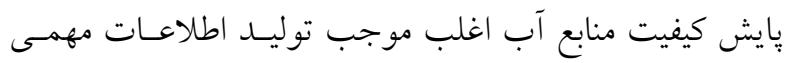

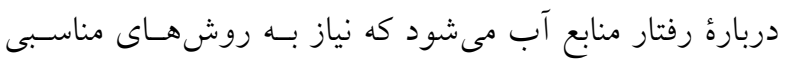

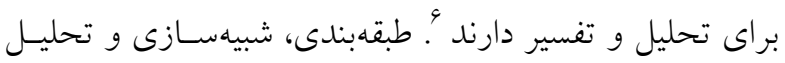

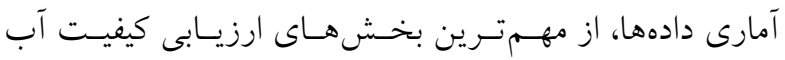

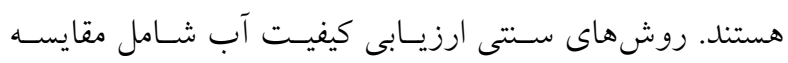

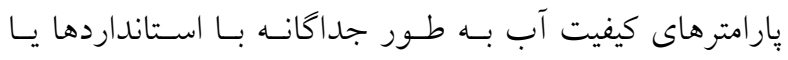

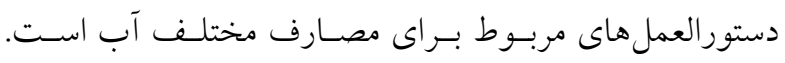

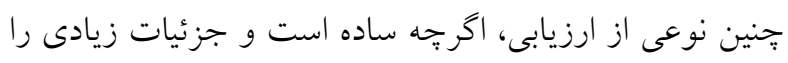

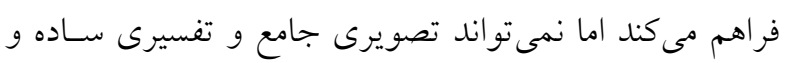


ورودى به شهر تهران و رودخانسء كـرج يكسى از يـرآبتـرين

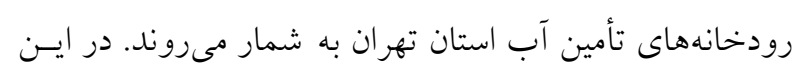

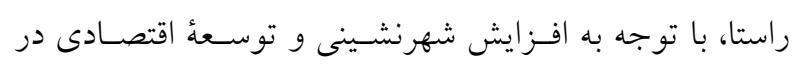

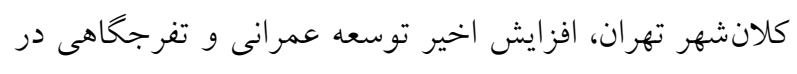

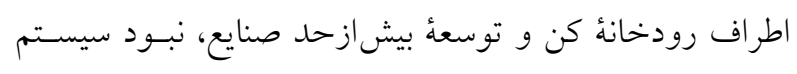

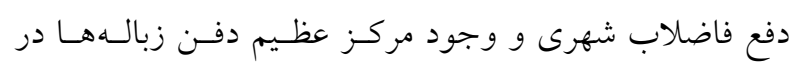

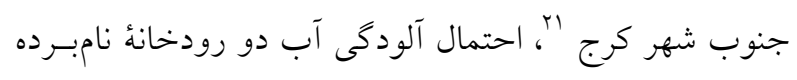

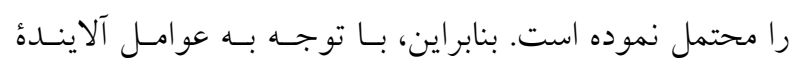

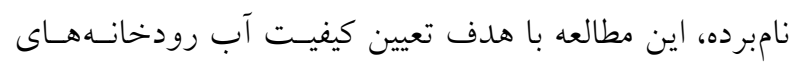

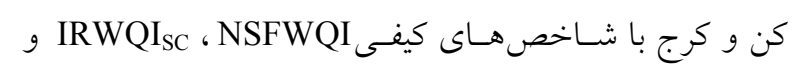

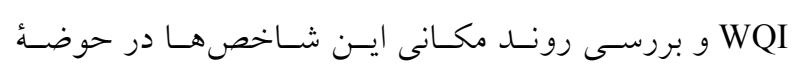
رودخانهاى كن و كرج طراحى گرديد.

\section{مواد و روشها}

\section{منطقه مورد مطالعه}

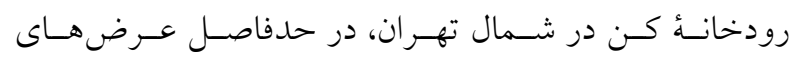

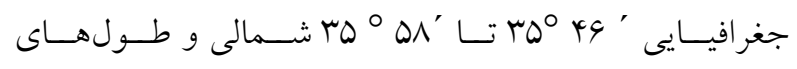

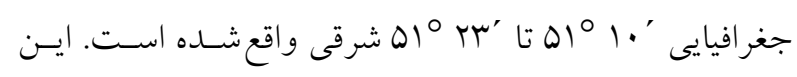

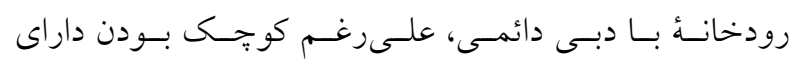
ويزگ كى هاى منحصربه فردى مانند موقعيت خاص جغر افيـايى و

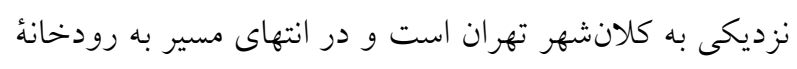

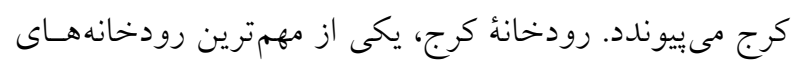

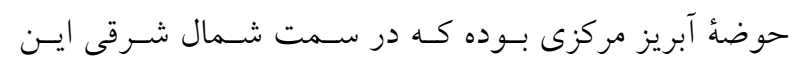

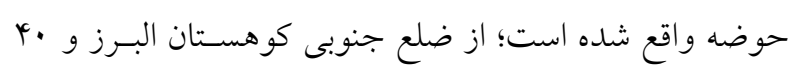
كيلومترى غرب تهران، از كانون آبخير خرسنى كوه سر جشمه ونه

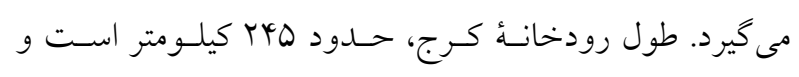

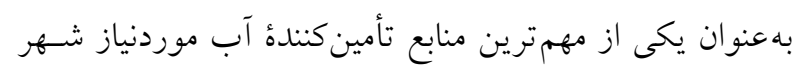

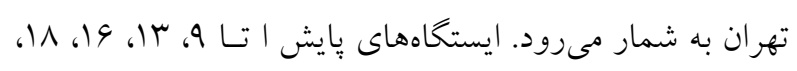

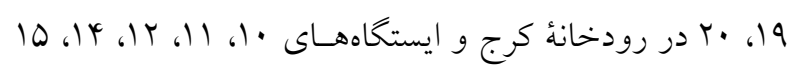
و IV در رودخانه كن واقع شدهاند. در شكل ا موقعيت منطقة
در ايران طراحى شده و يكى شاخص عمـومى و كـاربردى در

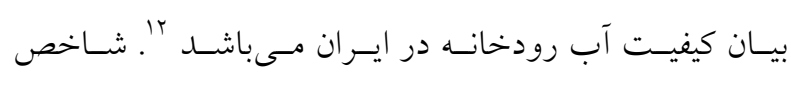

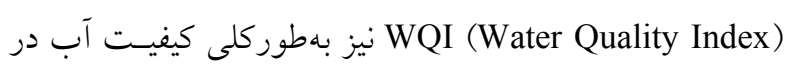

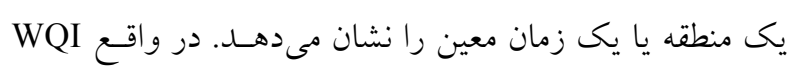

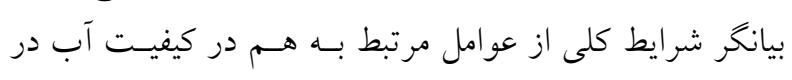

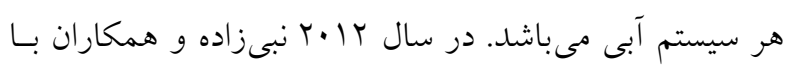

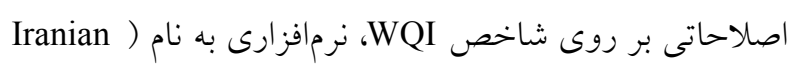
IWQIS (Water Quality Index Software آب با تكيه بر مدلها و شاخصه هاى كيفى تهيه كردنـد كـه در

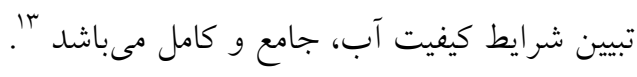

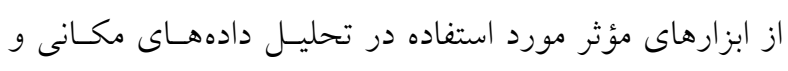

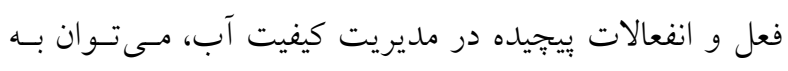
سيستم اطلاعـات جغر افيـايى (Seographical Information

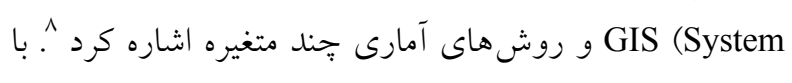
كمك GIS، محققان قادرند به سرعت خصوصيات و تغييرات

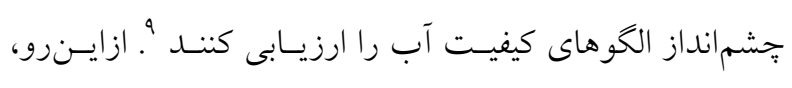
GIS

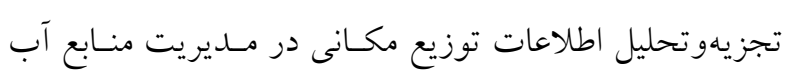
مى.باشد. تاكنون مطالعات متعددى در خصوص ارزيابى كيفيت آبهاى سطحى با استفاده از شاخصىهاى مختلف و روشهاى مآ آمـارى

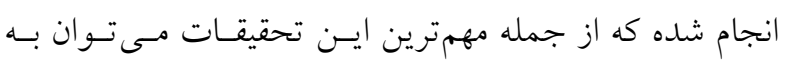

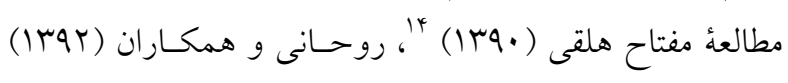

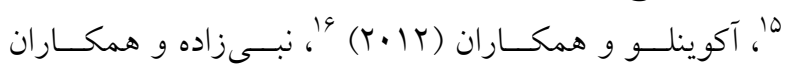

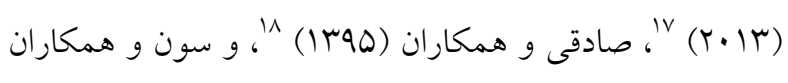

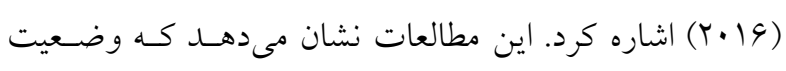
كيفيت منابع آب سطحى در فصول و ماههـاى مختلـف متغيـر

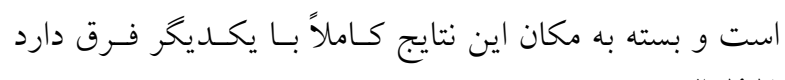

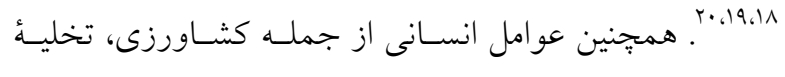
فاضلاب ها و صنعت مهم ترين منـابع آلـودگى رودخانسهــاى

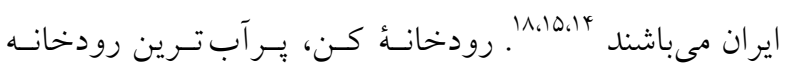


مطالعاتى و ايستخاههاى پِايش در رودخانهُ كن در استان تهران

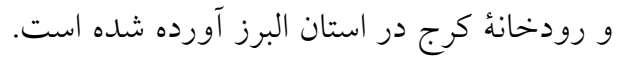

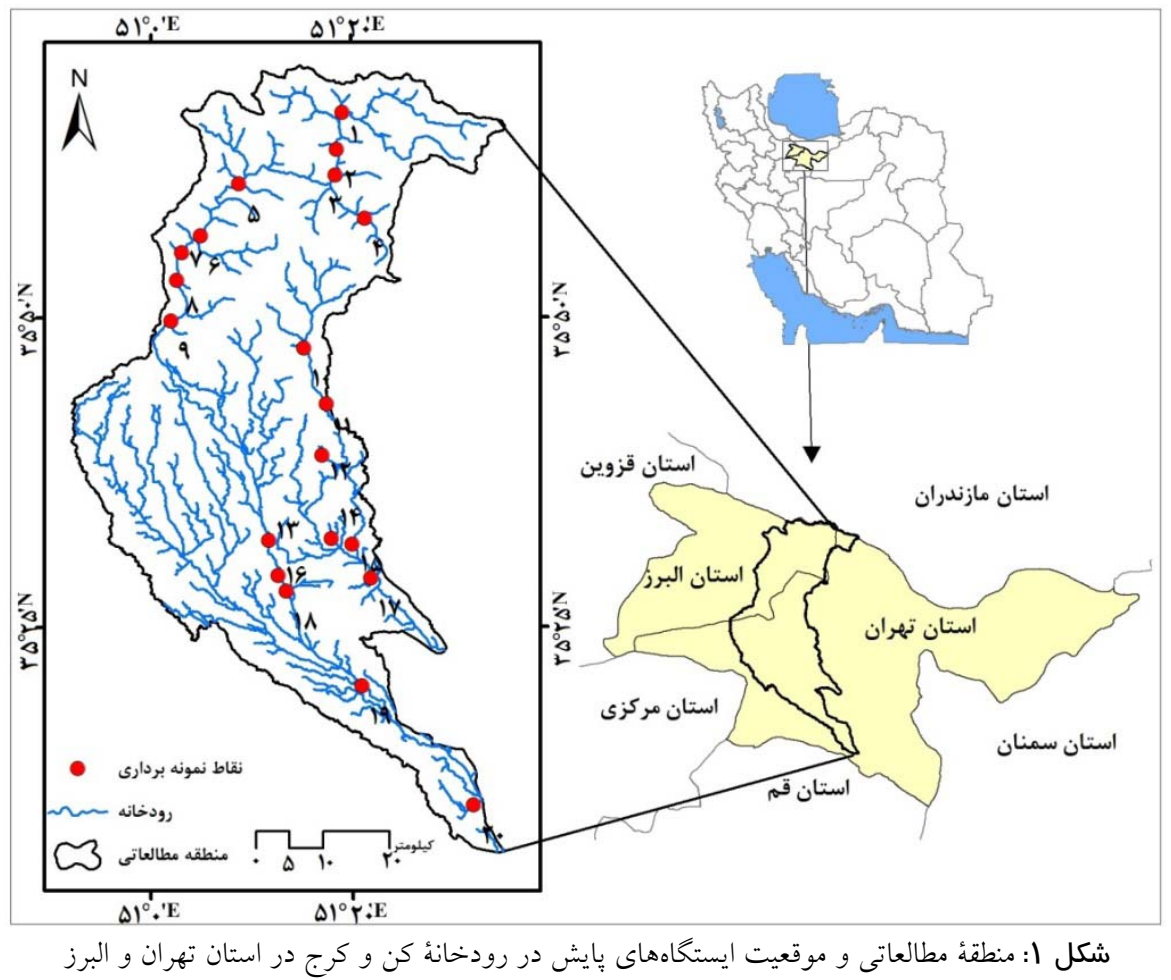

تغييرات به عنـوان ضــيبى بــراى ارزيـابى تغيير يـــيرى كلـى روش تحقيق

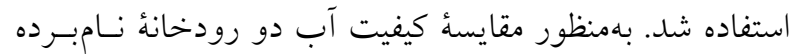
براى مصرف شرب، مقادير ميانخين بارامترها با مقدار حسداكثر در ايـن مطالعـه، اطلاعـات هشـت رِـارامتر كيفيـت آبـ

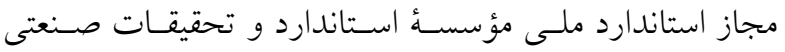

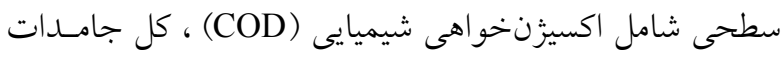
محلول (TDS)، هدايت الكتريكى (EC) ، كـدورت، نيتـرات، ايران (بهم·ا، تجديدنظر هـنجم) و سـازمان بهداشـت جهانى

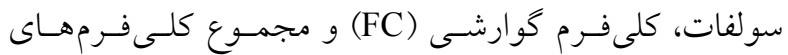

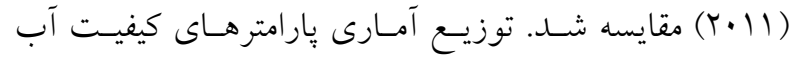

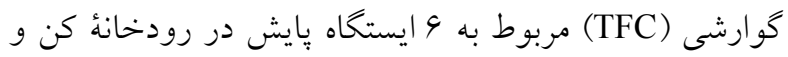
توسط آزمون شاييرو -ويلك بررسى شد. سبس مقدار ميانكَين

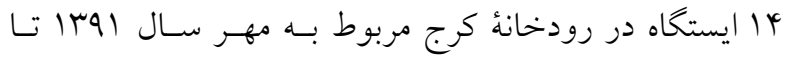

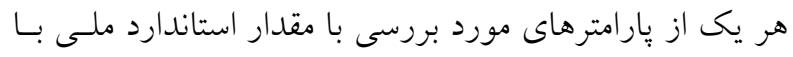

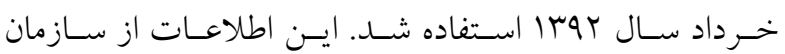

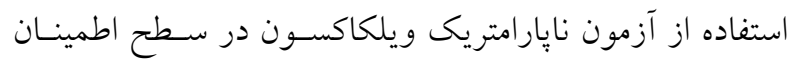
حفاظت محيطزيست و شـركت آب منطقـهـاى اسـتان تهـران

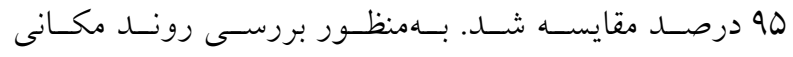
دريافت شد. بهمنظور بررسى دادهها، خلاصـهاى از اطلاعـات

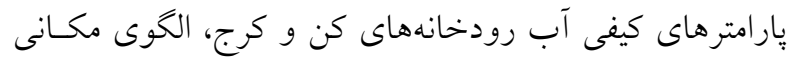

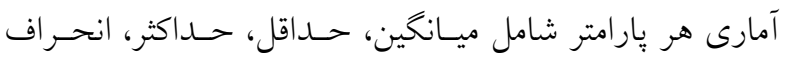

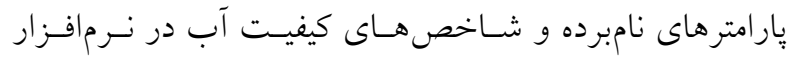

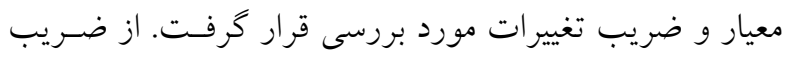


$\operatorname{IRWQI}_{S C}=\left[\prod_{\mathrm{i}=1}^{\mathrm{n}} \mathrm{I}_{\mathrm{i}}^{\mathrm{W}_{\mathrm{i}}}\right]^{\frac{1}{\gamma}}$

$\gamma=\sum_{i=1}^{n} W_{i}$

رابطة (Y)

رابطة (r)

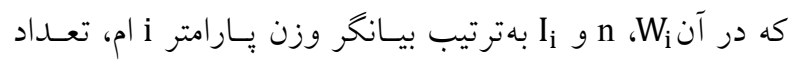

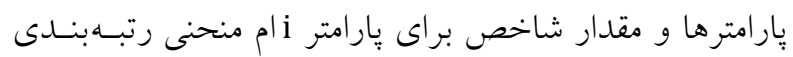
مى باشند.

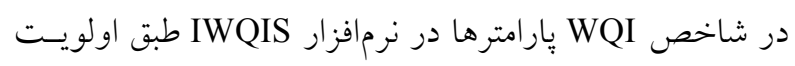

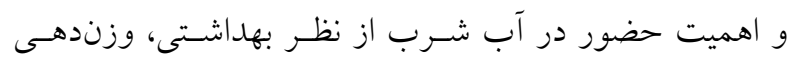

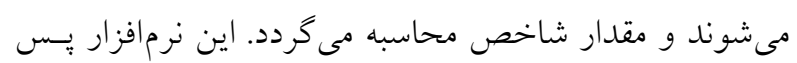

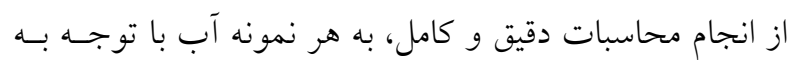

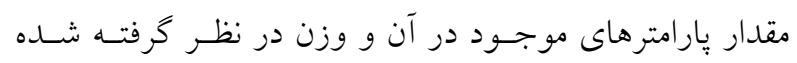

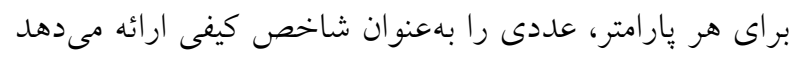

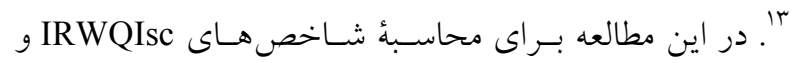
NSFWQI براى محاسبة شـاخص WQI از پِارامترهـاى TDS، نيتـرات و

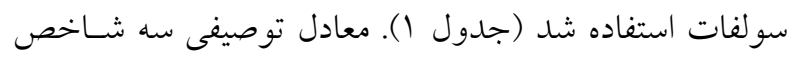

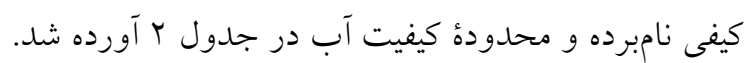

ArcGIS

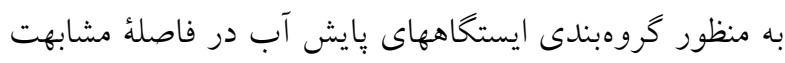

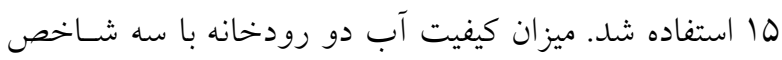
كيفى IRWQISC NSFWQI و WQI بررسى و طبقـهبنـدى

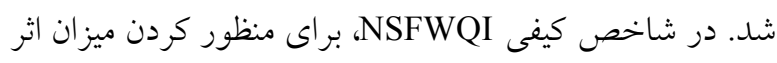

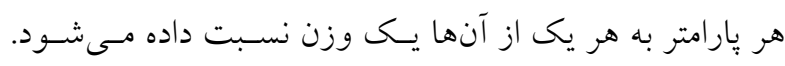

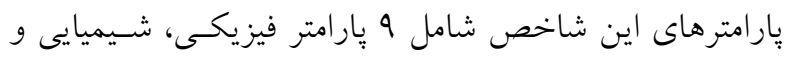

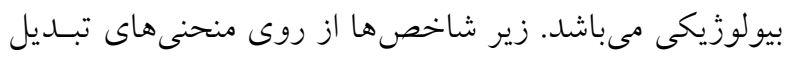

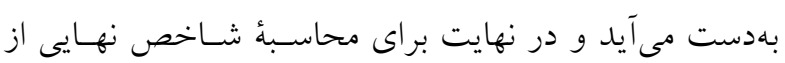
رابطؤ زير استفاده مى گردد:

$N S F W Q I=\sum_{i=1}^{n} W_{i} I_{i}$

رابطة (1)

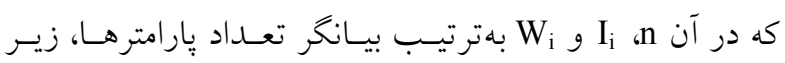
شاخص i ام و ضريب وزنى يارامتر i ام مىباشد.

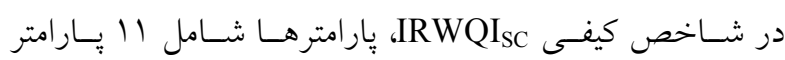

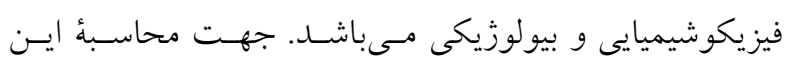
شاخص، با توجه به منحنى هاى هر كــدام از يّارامترهـا، مقــدار

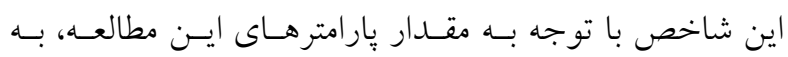
وسيلة رابطههاى ب و ب بهدست آمد:

جدول ا: يارامترهاى شاخصهاى كيفى IRWQISC NSFWQI و WQI و وزنهاى آنها

\begin{tabular}{|c|c|c|c|c|c|c|c|c|}
\hline كدورت & TDS & COD & TFC & $\mathrm{FC}$ & سولفات & نيترات & $\mathrm{EC}$ & يّار امترها \\
\hline$\cdot / \cdot \wedge$ & $\cdot / \cdot V$ & - & - & .19 & - & $\cdot / \cdot 1$ & .119 & وزن يّارامتر در شاخص \\
\hline .1 .94 & - &.$/ .94$ & - & $\cdot / 14$ & - & $\cdot / 1 \cdot 1$ & .1 .99 & $\begin{array}{c}\text { وزن پِارامتر در شاخص } \\
\text { IRWQISC }\end{array}$ \\
\hline- & r & - & - & - & r & 0 & - & وزن يّارامتر در شاخص \\
\hline NTU & $\mathrm{mg} / \mathrm{L}$ & $\mathrm{mg} / \mathrm{L}$ & $\begin{array}{c}\mathrm{MPN} / 100 \\
\mathrm{~mL}\end{array}$ & $\begin{array}{c}\mathrm{MPN} / 100 \\
\mathrm{~mL}\end{array}$ & $\mathrm{mg} / \mathrm{L}$ & $\mathrm{mg} / \mathrm{L}$ & $\mu \mathrm{s} / \mathrm{cm}$ & واحد اندازهيرى \\
\hline
\end{tabular}


جدول r: محدوده و معادل توصيفى شاخصهاى كيفى NSFWQI و IRWQI

\begin{tabular}{|c|c|c|}
\hline معادل توصيفى & محدودهُ شاخص & شاخص كيفى \\
\hline عالى & $1 \cdots-9$ & \multirow{5}{*}{ NSFWQI } \\
\hline خوب & $q \cdot-v \cdot$ & \\
\hline متوسط & $V \cdot-Q \cdot$ & \\
\hline بد & $\Delta \cdot-r \Delta$ & \\
\hline خيلى بد & $r Q_{-} \cdot$ & \\
\hline خيلى بد & كمتر از 10 & \multirow{7}{*}{$\mathrm{IRWQI}_{\mathrm{SC}}$} \\
\hline بد & $10-r 9 / 9$ & \\
\hline نسبتاً بد & $r \cdot-r t / q$ & \\
\hline متوسط & $\varphi \Delta-\Delta \omega$ & \\
\hline نسبتاً خوب & $\Delta \Delta / 1-V$. & \\
\hline خوب & $\vee \cdot / l-\wedge \Delta$ & \\
\hline بسيار خوب & بيشتر از ه & \\
\hline عالى & كمتر از •ه & \multirow{5}{*}{ WQI } \\
\hline خوب & $0 \cdot-1 \cdots$ & \\
\hline ضعيف & $1 \cdots-r \cdots$ & \\
\hline خيلى ضعيف & $r \ldots-r \ldots$ & \\
\hline نامناسب & بيشتر از ... & \\
\hline
\end{tabular}

يارامترها در دو رودخانه بيانكر آن است كه يراكنـدگى مقـدار بارامترها در رودخانهُ كن بيش از رودخانه كرج است كه ايسن موضوع نشاندهندة اين است كه ممكن است عوامل مختلفى

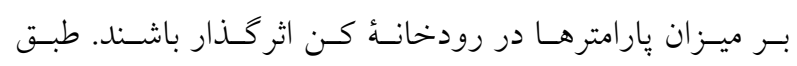

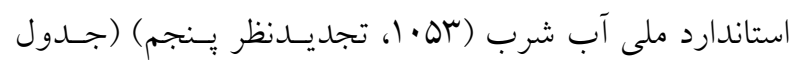

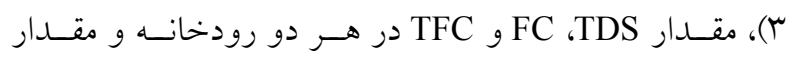
كدورت در رودخانهُ كن بيشتر از حـــاكثر مجــاز بــود. مقـدار بيشتر از ميزان حداكثر مجاز بِارامترهاى كيفى طبـق اسـتاندارد

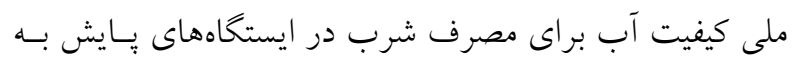

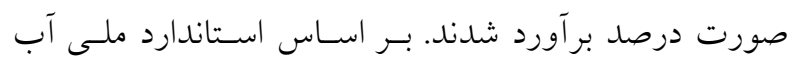

\section{يافتها}

طبق اطلاعات آمارى هر پِارامتر (جــول ب)، در رودخانـهُ كـرج، كمتــرين مقــدار و بيشـترين مقــار ضـريب تغييـرات بهترتيب مربوط به يارامترهاى كدورت (YY ا درصد) و COD (اTM درصد) و در رودخانه كن، كمتـــين مقـدار و بيشـترين مقدار ضريب تغييرات بهترتيب مربوط به يارامترهـاى نيتـرات

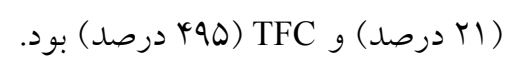

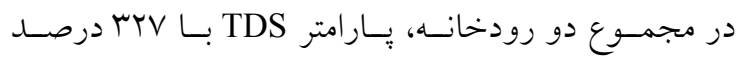

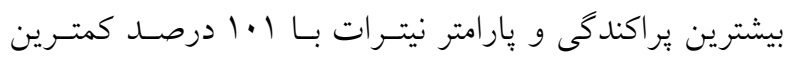

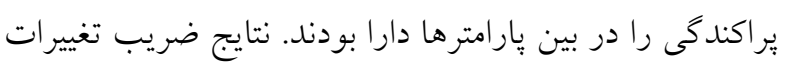




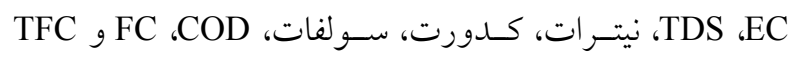

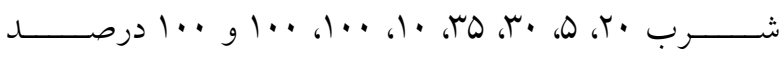

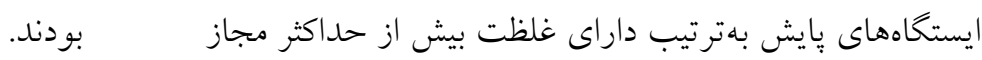

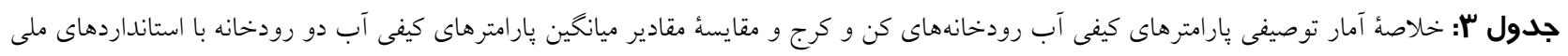

\begin{tabular}{|c|c|c|c|c|c|c|c|c|}
\hline TFC & FC & سولفات & نيترات & كدورت & TDS & EC & COD & يار امتر \\
\hline \multicolumn{9}{|c|}{ رودخانه كرج } \\
\hline $499 \cdot 1 / 4 \Lambda^{*}$ & 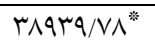 & 19911 & $\mid r / \mu \Lambda$ & $14 / 19^{*}$ & $191 / 9 \mathrm{~V}$ & $19 \cdot V / T Y$ & $\Delta 4 / 9 q^{*}$ & ميانخين \\
\hline r & $r$ & $r$. & $\cdot / \Lambda$ & $1 / 0$ & 9. & TYG & r & حداقل \\
\hline $\mid v \ldots \ldots$ & $\mid v \ldots \ldots$ & $\wedge r q / 1$ & $\Delta r / q$ & or & $9 O V Y / r$ & $11 r q \pi / r$ & $1 \cdot r$. & حداكثر \\
\hline$V \cdot \Delta r Y / Y I$ & GTVTY/QG & TMr/Y. & $19 / 1 Y$ & $1 V / 9 \Lambda$ & $|V| \Lambda / A$ & $r 9 Y 9 / 90$ & TVT & انحراف معيار \\
\hline 10. & 191 & 1149 & lOF & IYY & $19 r$ & lN & MYI & ضريب تغييرات \\
\hline \multicolumn{9}{|c|}{ رودخانه كن } \\
\hline$\Lambda Q 1 Y Q^{*}$ & $\vee Y \Lambda \cdot \Delta / \Delta \Delta^{*}$ & $1 \cdot 9 / r 1$ & $41 / 94$ & $r / M$ & $\Delta V \Lambda / \Delta Q$ & $1 \cdot \Delta r / 1 Y$ & $\mu / \cdot \wedge^{*}$ & ميانخين \\
\hline MYQ.. & mo.. & MN/GV & TV/TG & $\cdot / 9$ & $Y \cdot Y / \wedge G$ & raq/VI & IV/TY & حداقل \\
\hline $1400 \ldots$ & $1 \cdot r \ldots$ & $r Y q / \cdot r$ & $r q / 9 r$ & $Y / A r$ & $1.19 / 19$ & IVNN/Tq & $\Delta Q / \Lambda r$ & حداكثر \\
\hline KYTIN/Y. & TrG八Q/TY & $G M / Q V$ & $1 / 9$. & $1 / 40$ & $r 99 / 99$ & $491 / 11$ & $1 V / 94$ & انحراف معيار \\
\hline 190 & rt & $\Delta \wedge$ & rI & 49 & 49 & kr & Qr & ضريب تغييرات \\
\hline \multicolumn{9}{|c|}{ دو رودخانه } \\
\hline$\Delta \Lambda K^{\prime} G \Lambda / K^{*}$ & $49.99 / 01 \%$ & $14 q / \cdot 9$ & $r I / T Q$ & $1 \cdot / \wedge V^{*}$ & VQV/VQ & $|K| T \mid / r$. & $99 / Y^{*}$ & ميانخين \\
\hline r & $r$ & $r$. & $\cdot / \Lambda \Lambda r$ & $\cdot / 198$ & 9. & TYG & r & حداقل \\
\hline $\mid v \ldots$ & $\mid v \ldots$ & $\Lambda r q / 1 r$ & $\Delta r / q F$ & or & GOVT/MT & سז/4rar & $1 \cdot r$. & حداكثر \\
\hline grVVD/r. & $\Delta \Delta 919 / .4$ & $199 / 11$ & YI/OF & $10 / \Delta r$ & IKra/vG & YYAY/G. & rYG/VG & انحراف معيار \\
\hline 11. & $11 \%$ & IrT & 1.1 & IKT & 189 & iv. & rTV & ضريب تغييرات \\
\hline · & · & $\psi_{\ldots}$ & 40 & $\Delta$ & $10 \ldots$ & $r \cdots$ & - & حداكثر مجاز در استاندارد \\
\hline . & . & ro. & ra & $\Delta$ & $9 .$. & $10 \ldots$ & - & $\begin{array}{r}\text { حداكثر مجاز در استاندارد } \\
\text { WHO }\end{array}$ \\
\hline
\end{tabular}

ميانخين COD، و FC و TFC در ايستخاههــاى يـايش بـه طـور معنسى دارى بـيش از حسـداكثر مجــاز در اسـتاندارد ملـى بــود

$$
(p<\cdot / \cdot ه)
$$

با توجه به الكوى مكانى يارامترهـاى كيفـى آب، كمتـرين غلظت بارامترها بهجز كدورت در مناطق بالادست ديده شد و بهتدريج با جريان رودخانه، بر مقـدار بيارامترهـا افـزوده شـــه

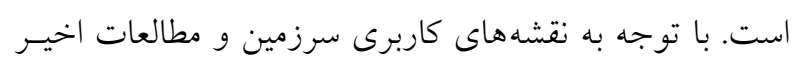

بهمنظور مقايسة آمارى مقــار ميـانخين يار امترهـاى مـورد

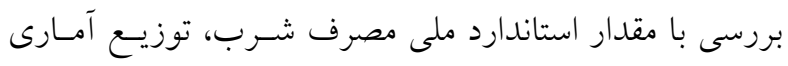
يارامترهاى كيفيت آب در ايستخاههاى بايش بررسى شد. طبق

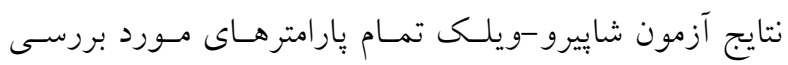

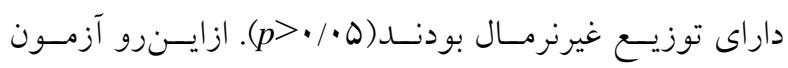

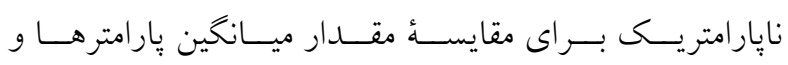

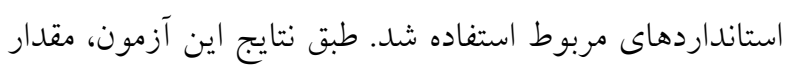




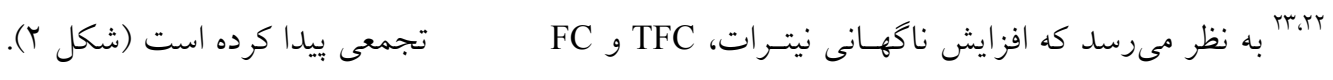

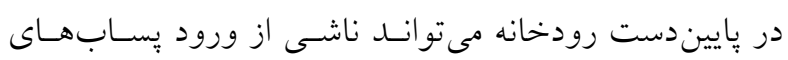

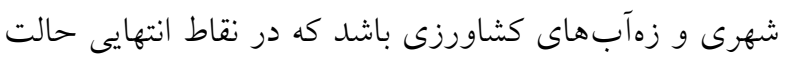

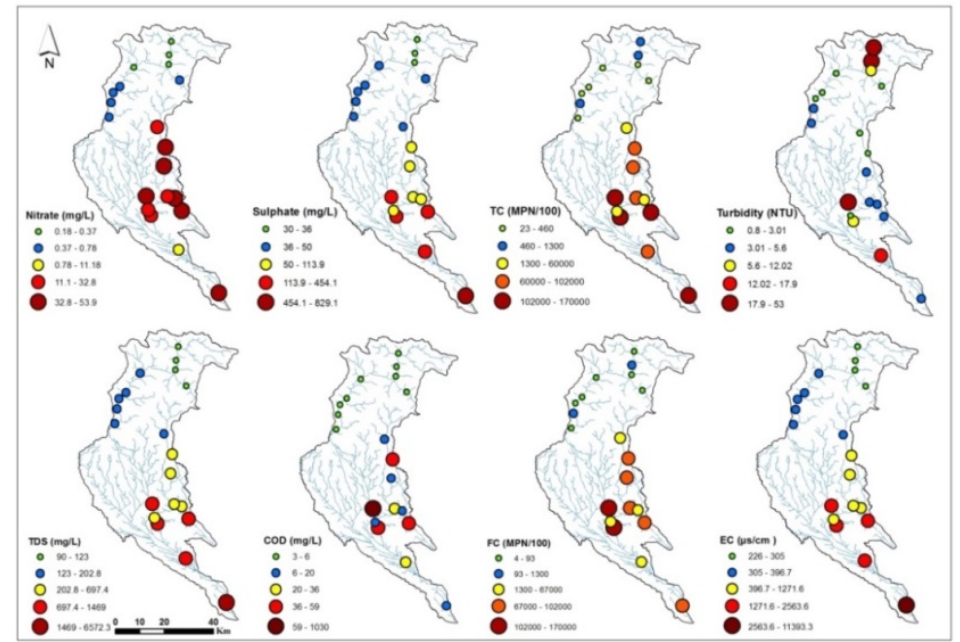

شكل r: الكوى مكانى مقادير پارامترهاى كيفى آب در ايستخاههاى بايش رودخانههاى كن و كرج

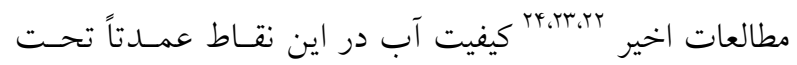
تأثير آلايندهاى صنعتى و فاضلاب خانكى بوده است. عـلاوه بر اين، ايستخاههـاى •ل، II، در خوشهُ دوم قرار دارند. اين ايستخاهها به مزارع كشـاورزى،

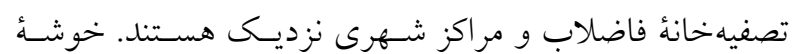
سوم شامل ايستخاههاى ا تا 9 مىباشد كه منابع آلاينده در اين نقاط كم مىباشد (شكل سم).
طبق نمودار دنــدروكرام، ايستخاههـاى يـايش آب در فاصـلة مشابهت ها لهـه سـه خوشـهُ معنسى دار كـروهبنـدى شــدهانـد. ايستخاههاى يايش آب در يك خوشه اغلب بيانخر ايسن اسـت كه ويزگ گى هاى محيطزيست اين نقاط به همديخر شبيه اسـت. خوشههاى دوم و سوم داراى طول زيرخوشهُ كوتاه هستند كـــ بيانخر تشابه درون گروهى در اين خوشهها مسىباشـد. ايسن در

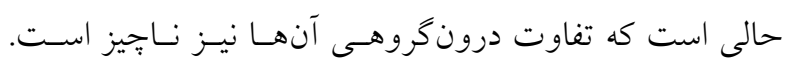

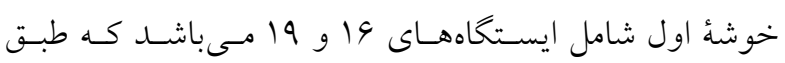




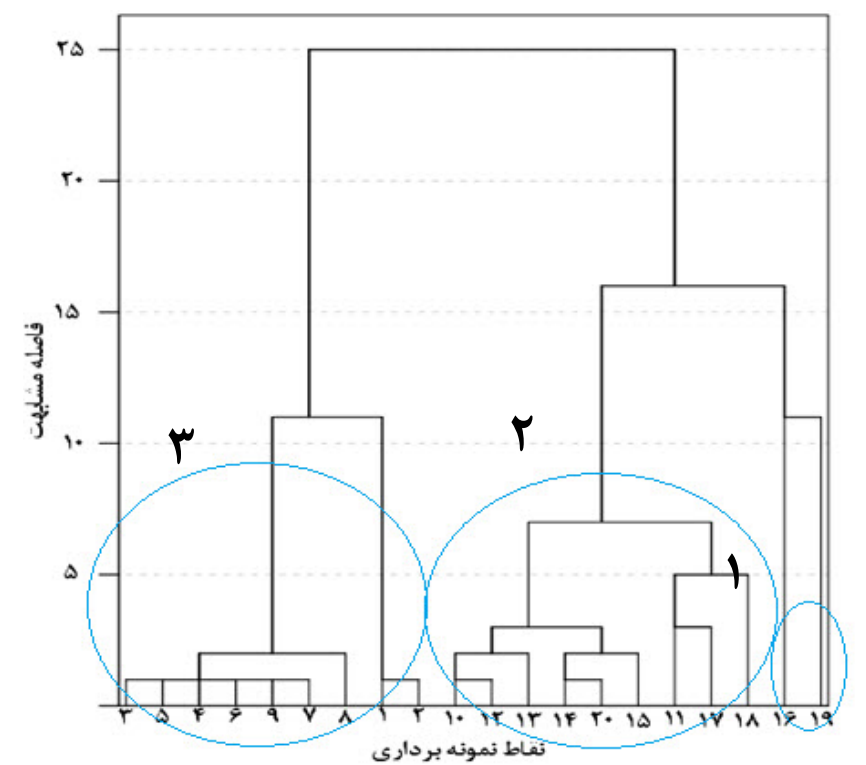

شكل بّ: دندرو كرام ايستكاههاى يايش رودخانهاى كن و كرج حاصل از تحليل خوشهاى برى

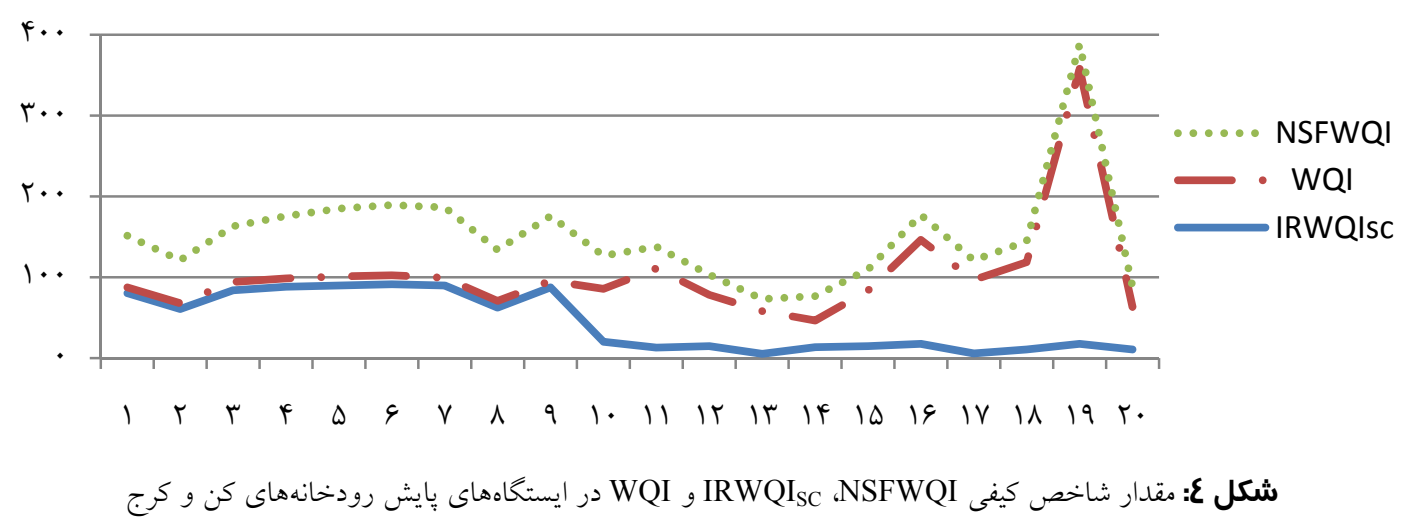

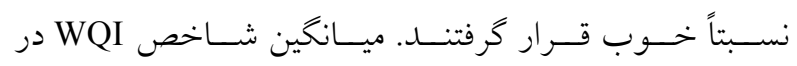

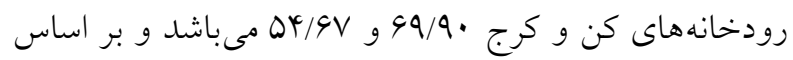

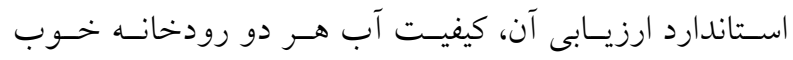

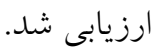
بر اساس الخوى مكانى مقادير شاخصهاى كيفى در ايستخاه-

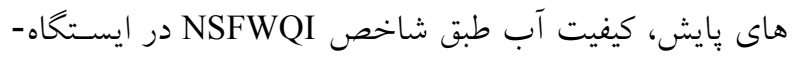

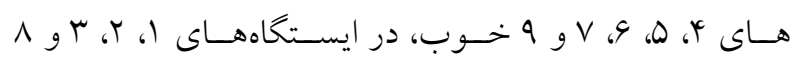

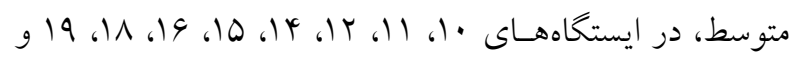

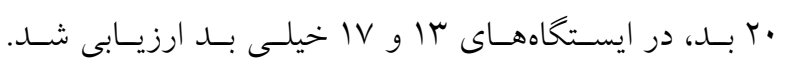

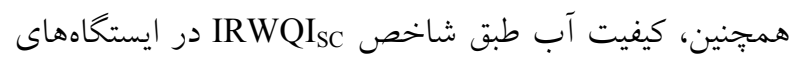

مقدار شـاخص IRWQIISC NSFWQI و WQI بـهترتيـب در

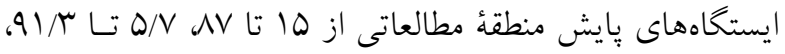

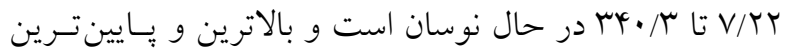

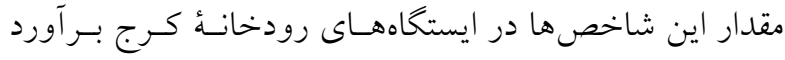

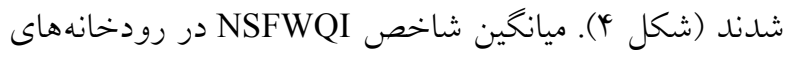

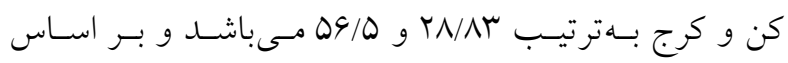

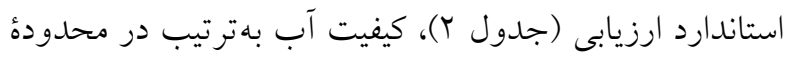

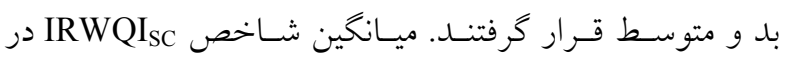

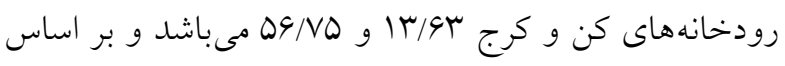

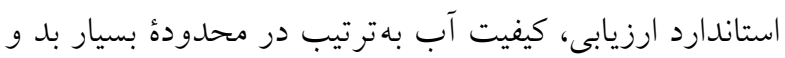


عـالى، در ايستخاههـاى ·لاتـا با، ها، VI و •r خــوب، در

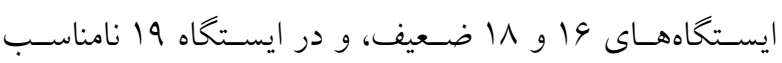

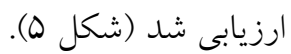

أ، ه، 9، V و 9 بسيار خوب، در ايستخاههاى او بخوب، در ايستخاههاى r و 1 نسبتاً خوب، در ايستخاههاى · ·1، 19 و 19

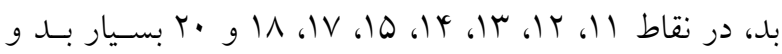
كيفيت آب طبق شاخص WQI در ايستخاههـاى ا تـا 9 و 14

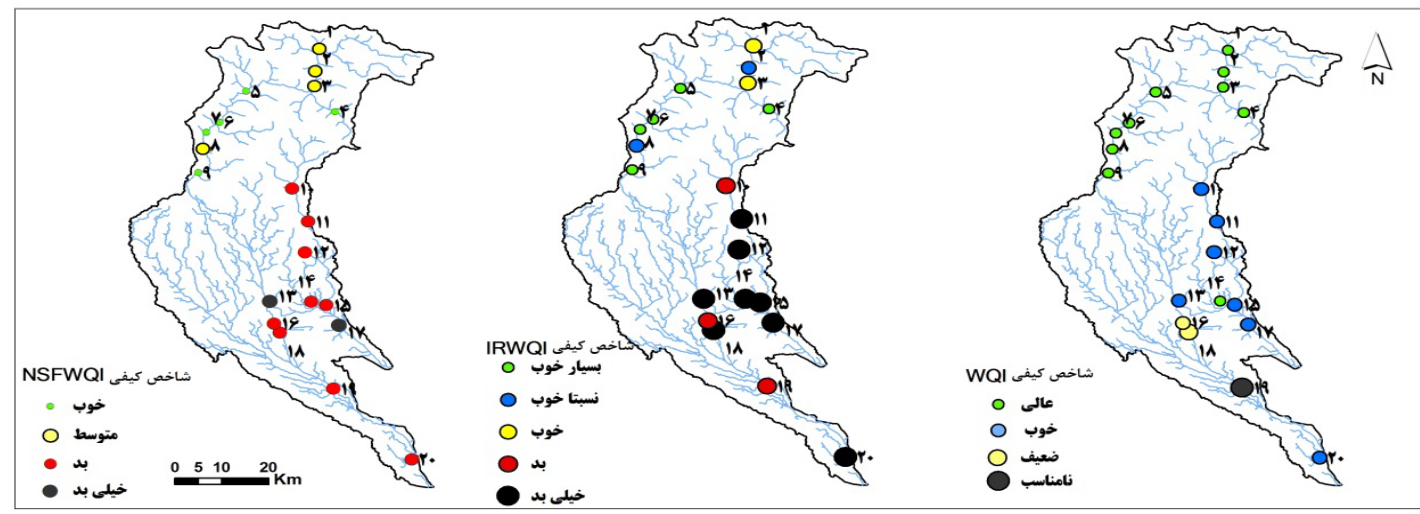

شكل ه: الخوى مكانى مقادير شاخص هاى كيفى NSFWQI و IRWQI ، در ايستخاههاى بايش رودخانهاى كن و كرج

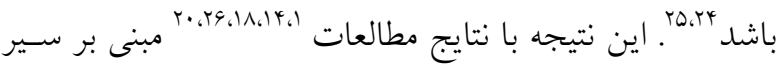

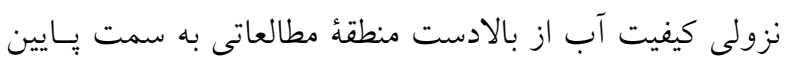
رودخانه همخوانى دارد. تمام اين مطالعات اشاره كردهانــ كـهـ با حركت از بالادست به ياييندسـت رودخانسه ممكسن اسـت

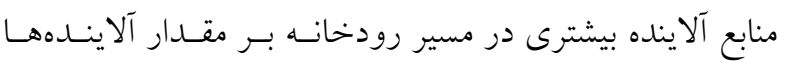
بيفزايند و مقدار آلايندهها در طى مسـير حالـت تجمعسى بيـدا كنند به شكلى كه خوديالايى رودخانه نيز توان كـاهش ميـزان آلودگى را به نحو مطلوب نداشته باشد. نتايج تحليل خوشهاى نيز نتايج الكوى مكانى يارامترها و شاخص هـاى كيفى آب را تاييــد كـــد. كيفيـت آب رودخانسههـاى كـن و كـرج طبـق شاخص هاى كيفى IRWQI و ISC ، در طبقه آبهاى با كيفيت بد و متوسط، بسيار بد و به نسـبت خـوب، خــوب قــرار كرفتــــ. دليـل كـاهش كيفيـت آب دو رودخانه در شاخصهاى نامبرده، وجود يّار امترهاى تأثيركـذار

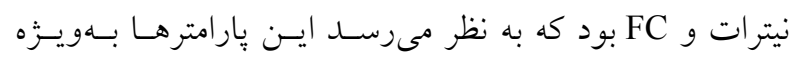
نيترات تحت تاثير كاربرى اراضى اطراف رودخانه مسىباشـند.

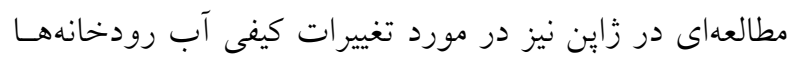
نشان داد كه نحوه استفاده از زمينهاى اطر اف رودخخانههـا بــر

\section{بحث}

در اين مطالعه، كيفيت آب رودخانههـاى كـن و كـرج بـا شــاخص هــاى كيفـى WQI IRWQI ، تحليل خوشهاى و سامانه اطلاعات جغرافيايى ارزيابى گرديد. از هشت يُارامتر كيفى موردمطالعه، در رودخانهُ كن سه يارامتر

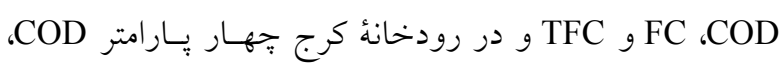
و و كدورت داراى غلظتهايى بيش از حداكثر مجاز FCC FC در استاندارد ملى مصرف شرب بودند.

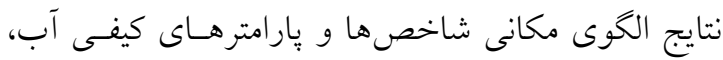

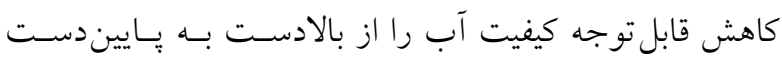
منطقــهُ مطالعـاتى در طــول سـالهــاى |qr| - $9 r$ نشـان داد. همجنين طبق اين نتيجه، منطقه را مىتوان به دو بخش شمالى با كيفيت بهتر و جنوبى با كيفيت بدتر آب تقسيم كرد. عواملى مانند وجود مناطق بكر، غلظت كم يار امترها بــهــز كـدورت، شيب زياد و فرسايش بيشتر خاك در نقاط بالادست و افزايش جمعيت، توسعهُ صـنعت و كشـاورزى و تخليـهُ فاضـالاب در نقاط باييندست ممكن است به افـزايش آلاينـدههـا در نقـاط انتهـايى در مقايسـه بــا نقـاط ابتـدايى حوضـه كمـك كـرده 
و طبق شاخص IRWQIISC در دو ردهُ متوسط و نسـبتاً خـوب

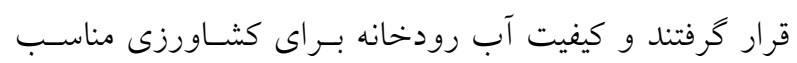

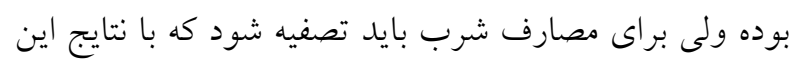

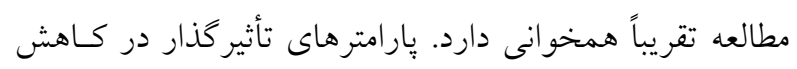

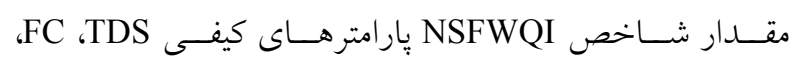

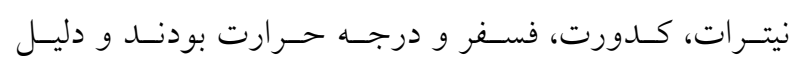

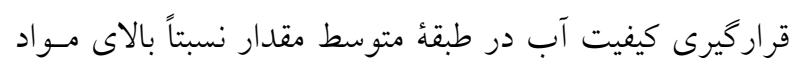

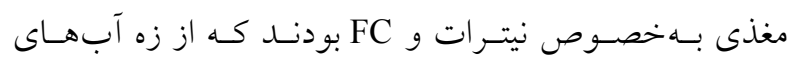

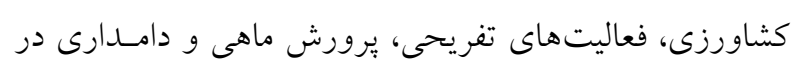

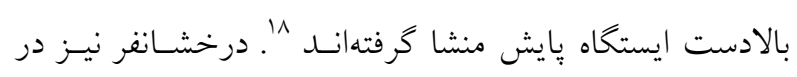

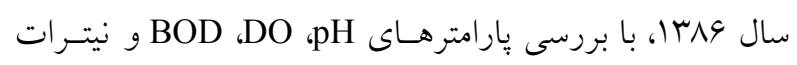

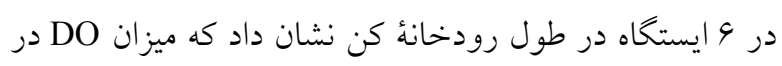

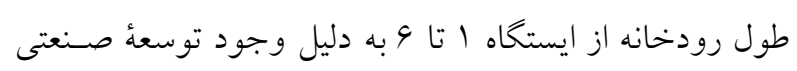

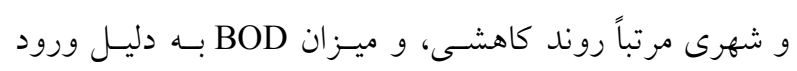

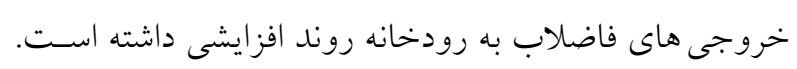

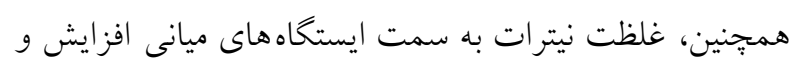
مجدداً به سمت ايستخاه هاى انتهايى كـاهش يافتـه كـه نتـايج

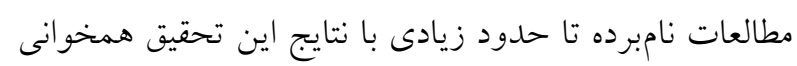
دارد

به هرحال با توجه بـهـ تفــاوت كيفيـت آب هـر منطقـهـ از

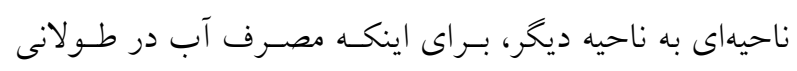

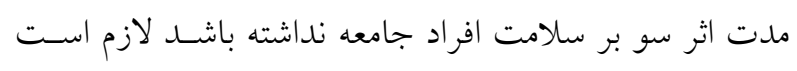
با استانداردهاى كيفى موجود مطابقت داشته باشد.

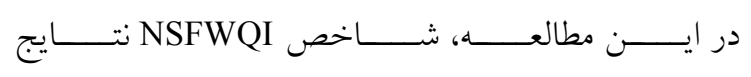

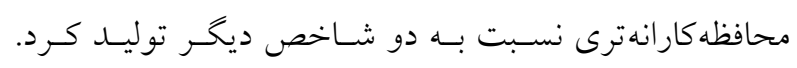

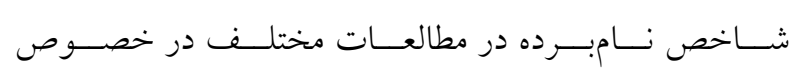

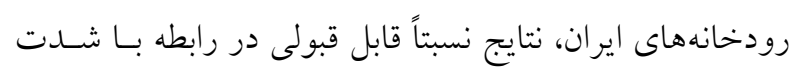

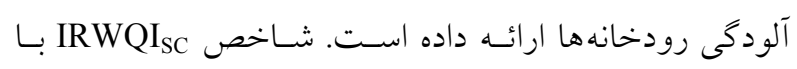

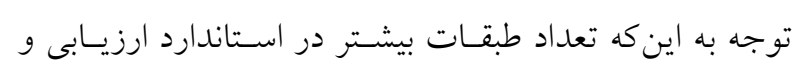

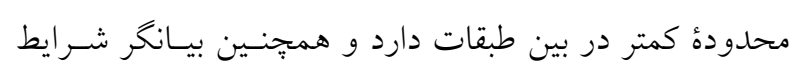

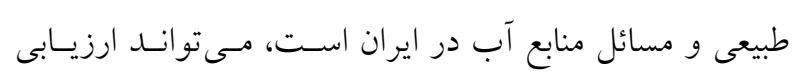

نوع و مقدار آلودگى و تغييرات آن اثر قابل توجهى داشته است

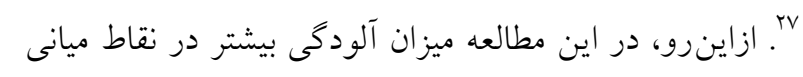

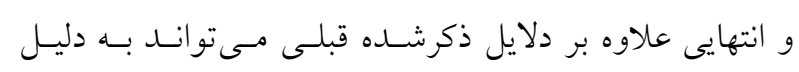

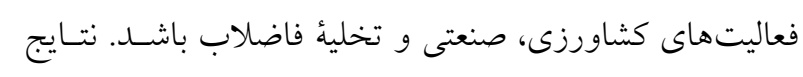

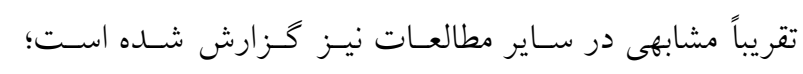

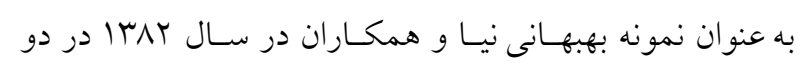

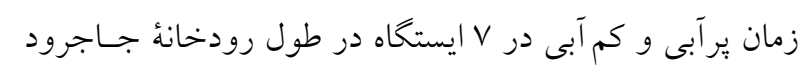

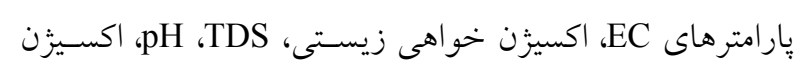

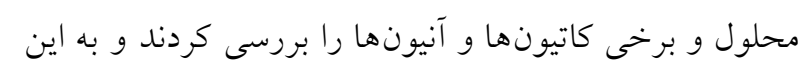

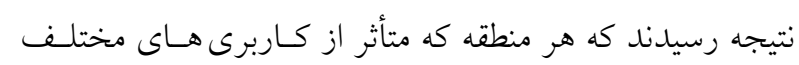

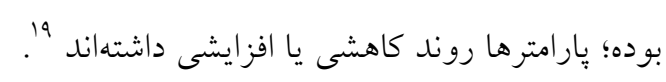

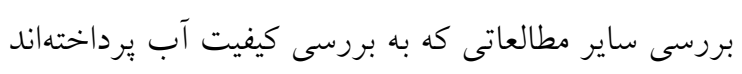

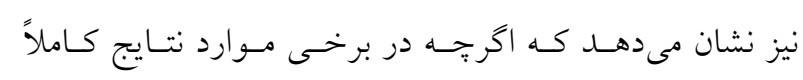

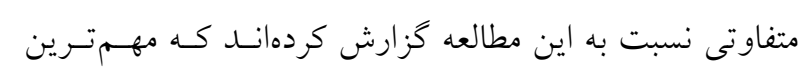

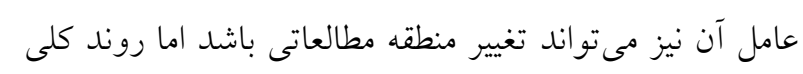

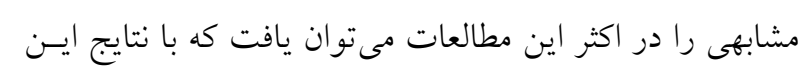
مطالعه همخوانى دارد. به عنوان نمونه، مفتـاح هلقـى در سـال

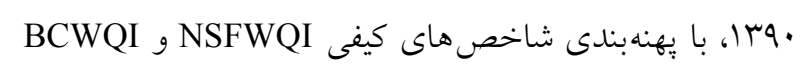

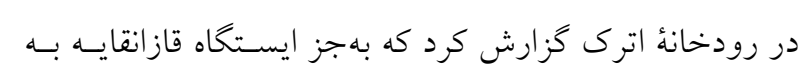

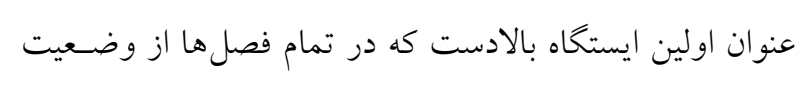

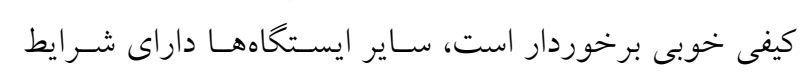
كيفى متوسط تا بد بودند ". سيهرنيا و همكاران نيـز در سـال

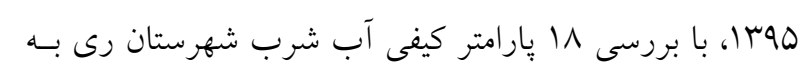

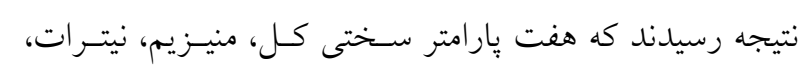

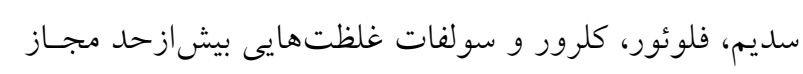

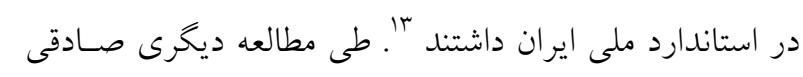

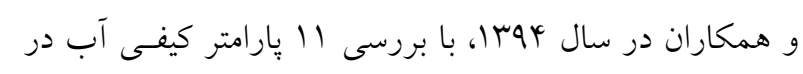

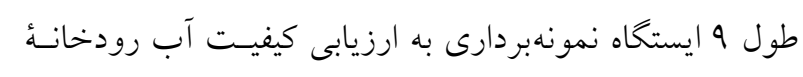

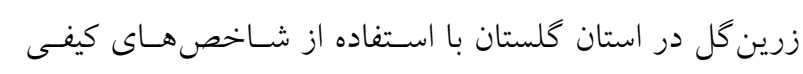

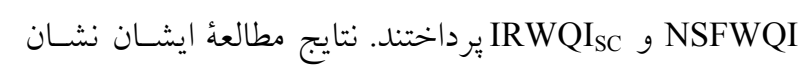
داد كه تمام ايستخاهها طبق شاخص NSFWQI در رده متوسط 


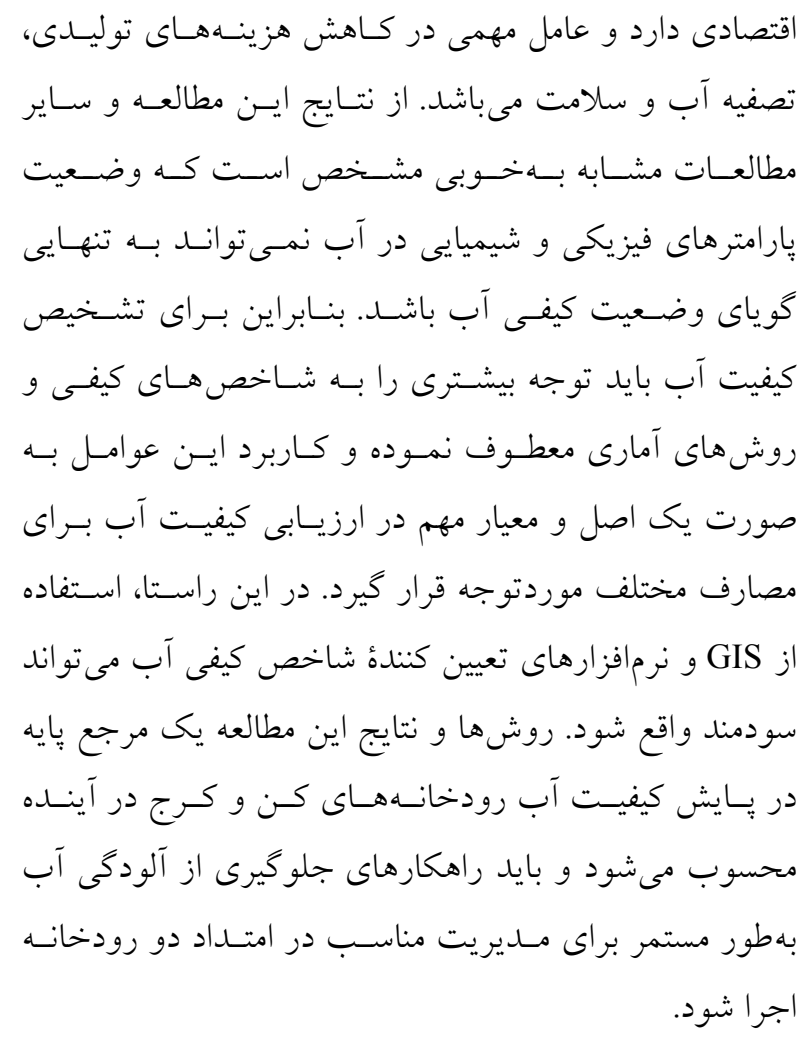

\section{References}

1. Sun W, Xia C, Xu M, et al. Application of modified water quality indices as indicators to assess the spatial and temporal trends of water quality in the Dongjiang River. Ecol Indicat 2016; 66: 306-12.

2. Atafar Z, Almasi A, Sarkhosh M, et al. Microbiological Quality Trend of Drinking Water in Rural Areas of Kermanshah during 2004-2013. J Environ Health Eng 2015; 4(1): 70-81. [In Persian].

3. Wang $\mathrm{Q}, \mathrm{Wu} \mathrm{X}$, Zhao B, et al. Combined multivariate statistical techniques, Water Pollution Index (WPI) and Daniel trend test methods to evaluate temporal and spatial variations and trends of water quality at Shanchong River in the Northwest Basin of Lake Fuxian, China. Plos One 2015; 10(4): 1-17.

4. Molaei Tavani S, Goodini H, Mehr Ali A, et al. Survey the Current State of Quality Potable Water Clearing Supplied to the Distribution System and the Role of Water \& Wastewater Company And the Distribution of Network and Improve Its Quality Case Study in Shahrood City. J Environ Health Eng 2016; 3(4): 298-312. [In Persian].

5. Orooji N, Takdastan A, Noori, et al. Evaluation the Quality of Bottled Waters Consumption in Iran in 2015. J Environ Health Eng 2016; (4): 70-81. [In Persian].

$$
\begin{aligned}
& \text { دقيقترى نسبت به دو شاخص ديخر ارائه داده باشد. اما نتـايج } \\
& \text { شاخص WQI، بيانخر شرايط كلى كيفيت آب بوده است؛ كـه } \\
& \text { اين نتيجه هم مىتواند بـه دليـل كمبـود دادههـاى موجـود در } \\
& \text { شاخص يا عدم لحاظ يار امترهاى تأثير گذار در شاخص باشد. } \\
& \text { به هرحال براساس تمام مطالب ذكرشـده مسىتـوان نتيجـهـ } \\
& \text { كرفت كه كيفيت آب در بالاى منطقة مطالعـاتى بـراى شـرب } \\
& \text { مناسب بوده ولى در نقاط ميانى و انتهايى براى شرب مناسـب }
\end{aligned}
$$

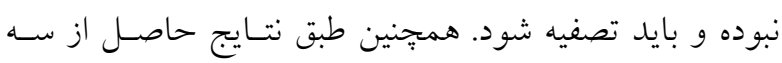

$$
\begin{aligned}
& \text { شاخص كيفى نامبرده، تأثير گذارى قابلتوجه وجود كلانشهـر } \\
& \text { تهران و وجود فعاليتهاى صنعتى و كشاورزى بر افت كيفيت }
\end{aligned}
$$

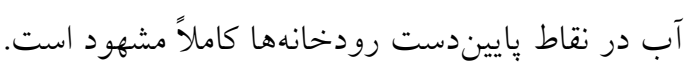

$$
\begin{aligned}
& \text { به هرحال آنجهه در مديريت منـابع آب شـرب قابـلتوجـه. } \\
& \text { است، بايش آن و جلو گيرى از بروز بيمارىهاى منتقل شونده }
\end{aligned}
$$

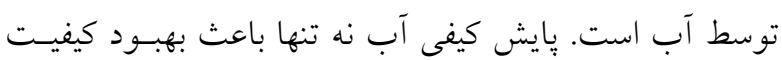

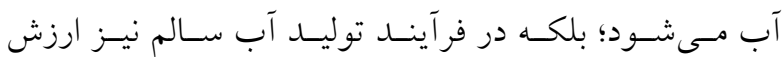

6. Sadeghi H, Ruhollahi S. Study of Ardabil Drinking Water Physicochemical Parameters. J Ardabil U Med Sci 2007; 7(1): 52-6. [In Persian].

7. Hoseinzadeh E, Rahimi N, Rahmani AR, et al. Quality Assessment of Takab Sarugh River Right Branch by Wilcox Index and It's Zoning Using Geographical Information System, 2011. J Mazand U Med Sci 2013; 23(103): 77-87. [In Persian].

8. Chang H. Spatial analysis of water quality trends in the Han River basin, South Korea. Water Res 2008; 42(13): 3285-304.

9. Li Y, Li Y, Qureshic S, et al. On the relationship between landscape ecological patterns and water quality across gradient zones of rapid urbanization in coastal China. Ecol Model 2015; 1-9.

10. Jonnalagadda SB, Mhere G. Water quality of the Odzi river in the eastern highlands of Zimbabwe. Water Res 2001; 35(10): 2371-6.

11. Narayan S, Chauhan R. Water quality status of river complex Yamuna at Panchnada (Distt.: Etawah, U.P., India), I: An integrated management approach. Pollut Res 2000; 19(3): 357-64.

12. Samadi J. Survey of Spatial-Temporal Impact of 


$$
\text { بررسى دوند مكانى شاخصهاى كيفى آب در حوضـأ رودخانه هاى كن و كرج }
$$

Quantitative and Qualitative of Land Use Wastewaters on Choghakhor Wetland Pollution Using IRWQI Index and Statistical Methods. Iranian Water Resour Res (IR-WRR) 2016; 11(3): 159-71. [In Persian].

13. Sepehrnia B, Nabizadeh R, Mahvi AH, et al. Water Quality Analysis of Drinking Water Distribution Systems of Rey Township Using IWQIS Software. Health Environ 2016; 9(1): 103-14. [In Persian].

14. Meftah Halaghi M. Use of Different Water Quality Indexes for Puriification of Water, Case Study: Atrak river. Water Soil Cons 2011; 18(2): 211-20. [In Persian].

15. Rohani N, Asadollah Fardi G. Detemining of water quality indices, Case Study: Inlet and outlet water treatment plant in Isfahan province. The 1 th Conference and Exhibition on Environmental Energy \& Clean Industry; 2-3 December 2013; Tehran: Tehran University. [In Persian].

16. Akkoyunlu A, Akiner ME. Pollution evaluation in streams using water quality indices: A case study from Turkey's Sapanca Lake Basin. Ecol Indicat 2012; 18: 501-11.

17. Nabizadeh R, Valadi Amin M, Alimohammadi M, et al. Development of innovative computer software to facilitate the setup and computation of water quality index. J Environ Health Sci Eng 2013; 11(1): 1-10.

18. Sadeghi M, Bay A, Bay N, et al. The survey of Zarin-Gol River water quality in Golestan Province using NSF-WQI

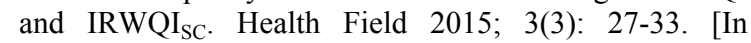
Persian].

19. Behbahaninia A, Salmasi R. The study of Jajrood River's physico-chemical properties and its pollutants. Human Environ 2008; 34-42. [In Persian].

20. Farzadkia M, Nasseri S, Rezaei Kalantary R, et al. Water Quality Zoning in Babolrood River Using National Sanitation Foundation Water Quality Index and
Geographic Information System. J Mazand U Med Sci 2016; 26(134): 357-62. [In Persian].

21. Firoozbakht A, Parhizkar A, Rabieifar V. Strategies of environmental structure city with approach urban sustainable development (Case Study: City of Karaj). Hum Geogr Res Q. 2012; (80): 213-39. [In Persian].

22. Alizadeh M, Mirzaei R, Kia SH.The Potential of LandCover/Use Detection using Landsat 8 Satelite Imagery (Case Study:Jajroud Basin). National Conference on Research and Technology Finding in Natural and Agricultural Ecosystems; 19 October 2016; Tehran: Tehran University. [In Persian].

23. Delkash M, Al-Faraj F.A.M, Scholz M. Comparing the Export Coefficient Approach with the Soil and Water Assessment Tool to Predict Phosphorous Pollution: The Kan Watershed Case Study. Water Air Soil Pollut 2014; 225(10): 1-17.

24. Alizadeh M, Mirzaei R, Kia SH. Detemining the Spatial Trend of Water Quality in Kan River Located in Tehran. National Conference on Research and Technology Finding in Natural and Agricultural Ecosystems; 19 October 2016; Tehran: Tehran University. [In Persian].

25. Sakizadeh M. Assessment the performance of classification methods in water quality studies, A case study in Karaj River. Environ Monit Assess 2015; 187(9): $1-12$.

26. Bateni F. The effect of land use on water quality of Zayanderood River. Department of natural resources Isfahan University of Technology; 2011. "thesis". [In Persian].

27. Teraoka H, Ogawa M. Behavior of elements in the Takahashi, Japan River basin. Environ Qual 1984; 13(3):453-9. 